\title{
Reproductive function of an organism of cows and rabbits at adding to ration of citrates of microelements
}

\author{
R. Fedoruk, \\ Corresponding Member of NAAS, Doctor of Veterinary Sciences \\ R. Iskra, \\ Doctor of Biological Sciences \\ Ya. Lesyk, \\ I. Kovalchuk, \\ Doctors of Veterinary Sciences \\ M. Khomyn, Candidate of Biological Sciences \\ Institute of Animal Biology, National Academy of Sciences of Ukraine
}

The purpose. To determine influence of citrates of microelements gained by the methods of nanotechnologies upon reproductive function of an organism of cows and rabbits. Methods. Physiological, zootechnical and statistical methods, and nano-technological substances. Results. Activating effect is fixed of citrate of Se (30 and $60 \mathrm{mkg}$ ), which was applied in a feed of cows in the first 2 months of lactation, on function of reproduction with decrease of amount of inseminations for $17,4-30,4 \%$ and service-period for 36,2-46,1\%. Complex application of citrate of Se in combination with citrates of $\mathrm{J}$, Co, $\mathrm{Cr}$ and $\mathrm{Zn}$ resulted in decrease of amount of inseminations for 18,2\%, and service-period for $28,3-29 \%$. Conclusions. Addition in feed compound of cows of citrate of Se in the first 2 months of lactation decreased amount of inseminations and service-period, preserving such action at combination of Se with citrates of $\mathrm{J}$, Co and $\mathrm{Zn}$. Addition in feed of rabbits of citrate of $\mathrm{Cr}$ and its combination with sulphate of $\mathrm{Na}$ increased resistance and reproductive function of their organism with increase of amount and masses of born rabbits.

Key words: reproductive function, resistance, cows, rabbits, service-period, citrates of microelements, nano-substances.

The problem of reproduction of the livestock population remains relevant in various livestock sectors, since it largely determines the effectiveness of its management [1-4]. Particularly important, the state of reproductive function of females acquires in the conditions of intensive livestock management, which is associated with a high level of its technical and technological support, stress, and hypodynamia [3-5]. To reduce the negative effects of these factors and increase the reproductive capacity of females used a number of drugs and biologically active agents containing trace elements $[1,4,6]$. Along with that, it is known that the mineral nutrition of the body of females significantly influences its sexual and physiological maturation, ovulation of oocytes, their fertility, embryonic and fetal development, and the mass of the offspring [3,5-8]. Therefore, in order to optimize mineral nutrition, ration of animals is enriched with macro- and microelements [5, 7, 9-11]. However, such elements are used as salts of mineral acids or oxides, which causes a number of side effects in the digestive tract and other systems of the animal body, and some of them ( $\mathrm{Se}, \mathrm{Co}, \mathrm{Cu}$ ) have close physiological and toxic levels.

In 2009, in Ukraine, unique nanotechnology for the production of carboxylates of most biotic elements has been developed, which makes it possible to use them to normalize the mineral nutrition of humans and animals $[6,12,13]$. A wide range of biological effects of these compounds has been established and their use for enrichment of raw materials and foodstuffs is allowed $[4,8,13]$. The compounds obtained in this nanotechnology in the form of citrates ( $\mathrm{Fe}, \mathrm{Cu}, \mathrm{Mn}, \mathrm{Mg}, \mathrm{S}, \mathrm{Si}, \mathrm{Se}, \mathrm{Co}, \mathrm{Ni}, \mathrm{Cr}$, etc.) have been investigated at the Institute of Animal Biology of the National Academy of Sciences of Ukraine. Characteristically, for most of the 20 investigated elements, the lethal doses of their citrates were 6-8 times larger than their mineral compounds. Application of micronutrient citrates increases their absorption 
and absorption, providing an effective biological effect in much smaller amounts [14, 15]. In particular, a number of positive biological effects have been established for the action of low (2-5 $\mu \mathrm{g} / \mathrm{kg}$ bodyweight) doses of these elements in both laboratory $[4,14,15]$ and productive $[3,8]$ animals.

The important results were obtained regarding the influence of these compounds on protein, lipid, carbohydrate metabolism, state of the immune and antioxidant systems of the animal organism, its resistance and productivity $[3,4,8,14]$. However, the effect of the carboxylates of biotic elements obtained on the basis of nanotechnology, on the reproduction of farm animals remains to be studied. Therefore, the purpose of the research was to determine the effect of citrates of trace elements obtained by the method of nanotechnology, on the reproductive function of the body of cows and the krolematok.

Materials and methods. Studies on cows are made on the basis of the state enterprise "DG Pasichna". Experiment 1 was conducted on 3 groups of cows-analogues, Ukrainian black-and-white milk breed, with productivity of 5.7-6.3 thousand $\mathrm{kg}$ of milk per lactation, 8 per each, formed in the first 2 weeks after calving in normalized feeding [ 7] in the control and 1-st (D 1) and 2-g (D 2) experimental groups. The cows D1 group daily, during the first 3 months of lactation, added to the mixed fodder citrate $\mathrm{Se}$, at a rate of $30 \mu \mathrm{g} \mathrm{Se} / \mathrm{kg}$ of dry matter, and D 2 - $60 \mu \mathrm{g} \mathrm{Se} / \mathrm{kg} \mathrm{c}$. Diet ration. Citrate Se was obtained by the method of nanotechnology [12] and provided for the research of "Nanomaterials and Nanotechnologies Ltd.", Kyiv.. The reproductive function of cows was controlled by the number of insemination with the definition of the fertilization index and the duration of the service period in days, after the examination of their cohesiveness and confirmation by the date of calving.

Experiment 2 was carried out on the same farm under similar conditions. The study was performed on 3 groups of cows-analogues, 5 in each, formed in the first month of lactation with tiredness of $22-26 \mathrm{~kg}$ of milk per day. Cows of the first experimental (D1) group received daily for 85-95 days of lactation with mixed fodder citrus of trace elements (CEM) in the following (mg): J-0.03, Cr-0.03, Se-0.025, Co-0, 1 and $\mathrm{Zn}-10 / \mathrm{kg}$ of dry matter of the diet (pp. Pp.). Animals of the 2nd experimental group (D 2) were fed (mg): $\mathrm{J}-0.06, \mathrm{Cr}-0.03$, Se-0.025 per kg with. P. The duration and scheme of these studies corresponded to the conditions of experiment 1.

Experiment 3 was carried out on rabbits of the breed "silver", body weight 3.9-4.2 kg, divided at the age of 110 days on the control and two (D 1, D 2) experimental groups, at 5 in each. Animals of all groups received feed and water flowing. Rabbits of group D1 released citrate $\mathrm{Cr}(\mathrm{C} 6 \mathrm{H} 5 \mathrm{CrO} 7)$ at a rate of $2.5 \mu \mathrm{g}$ $\mathrm{Cr} / \mathrm{kg}$ of body weight, and D $2-\mathrm{Cr}$ crude in the same amount with the addition of Na2SO4 at a rate of 41 $\mathrm{mg} \mathrm{S} / \mathrm{kg}$ body weight. In the studies, the rates of resistance in the blood of the krolematok were determined during the release of the $\mathrm{Cr}$ and $\mathrm{S}$ compounds, the reproductive capacity by the number of born proteins, and their preservation to 40 days of age, using general methods [16].

Research results. Introduction to the diet of cats of citrates of trace elements significantly changed their reproductive capacity. In particular, the addition of 30 and $60 \mu \mathrm{g}$ of Se contributed to a decrease in the number of inseminating insemination of cows by $17.4 \%$ (D1) and $30.4 \%$ (D2) groups (Fig. 1-A). In the cows of the control group, this index was kept within the range of 2.3 insemination. 

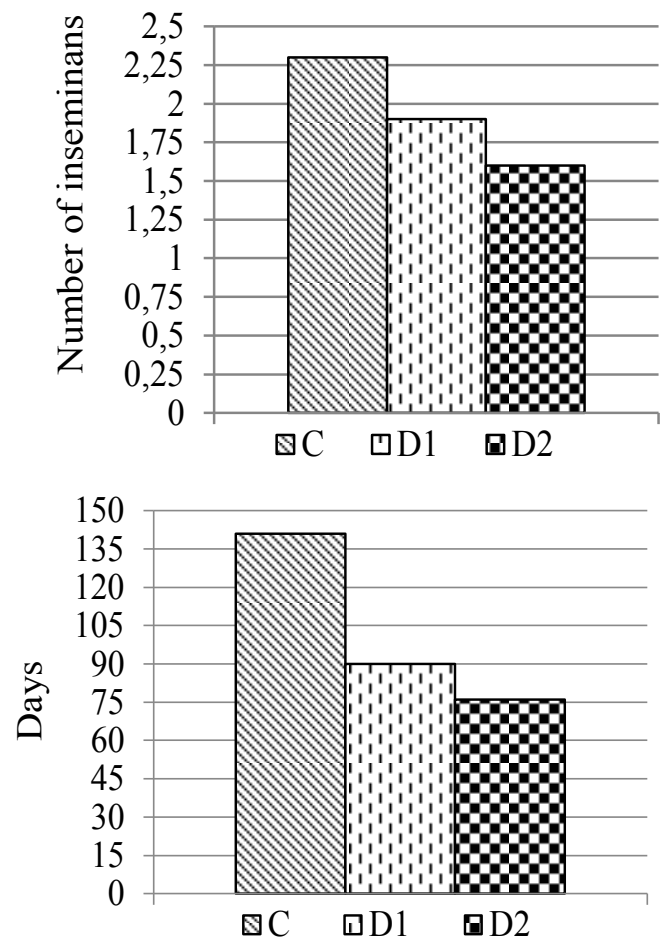

A - Number of insemination / insemination B - Service period, days

Fig. 1. Reproductive function of cows for inclusion in the diet of citrate Se

The stimulatory effect of Cit Cit on the reproductive function resulted in a decrease in the duration of the service period in cows D 1 and D 2 groups by 36.2 and $46.1 \%$, respectively (Fig. 1-B). The use of Citrate $\mathrm{Se}$ in a higher dose contributed to a more pronounced stimulatory effect on the fertility of D2 cows by the number of inseminants, and on the restoration of the reproductive cycle with a decrease in the duration of the service period. These data may indicate the feasibility of the inclusion of Cit Cit in the ration of lactation cows with the productivity of more than 5 thousand $\mathrm{kg}$ of milk per lactation.

Combined use of cows in the first period of lactation Se with other trace elements in the form of citrates retained this stimulant effect, but did not exceed it in the case of separate Se inclusion of the ration. In particular, in the group D1 cows fed Citrates Se, Cr, J, Co and Zn, the fertilization index was 1.8 and was lower by $18.2 \%$ compared with the control group (Fig. 2-A).
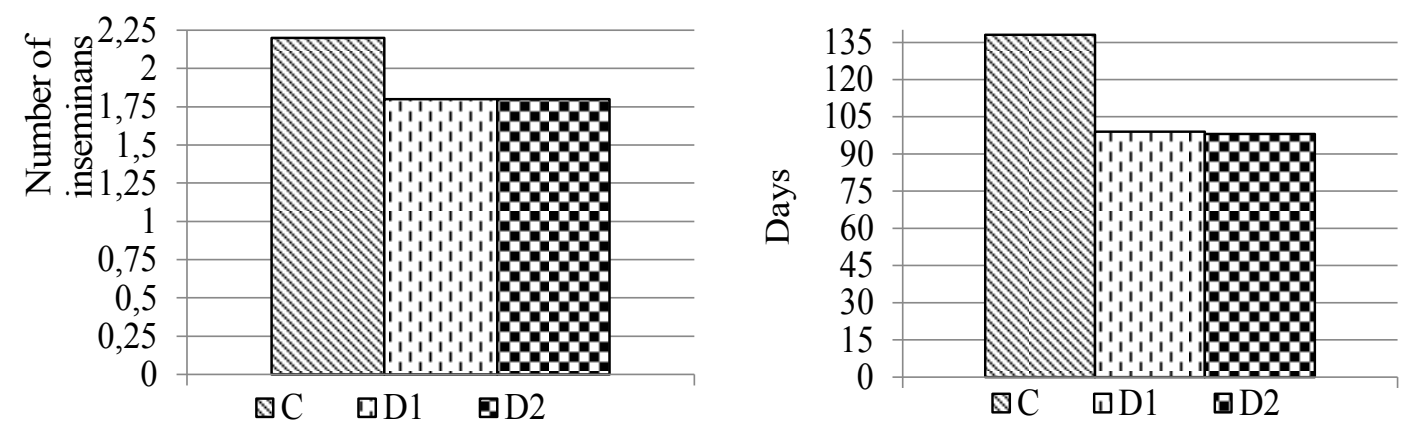

A - Number of insemination / insemination B - Service period, days

Fig. 2. Reproductive function of cows for the effects of citrates Se, Cr, I, Co and $\mathrm{Zn}$

A similar result was obtained in the group D 2 cows fed Cit, Se, $\mathrm{Cr}$ and $\mathrm{J}$. The duration of the service period in control and experimental groups of cows indicates a more pronounced effect of the applied doses of citrates of these trace elements on the restoration of sexual cycles in animals of experimental groups (Fig. 2-B). However, there are no significant differences in the service-period indices of cows of 
the 1st and 2nd experimental groups. The duration of the period from birth to fertilization in cows of the 1st and 2nd experimental groups was 99 and 98 days respectively, and was lower by 28.3 and $29.0 \%$, as compared to control. It is important to note that the duration of the service-period in control group cows varied within 103-187 days, while in D 1 - 67-123, and D 2 - 76-156 days. In 50-60\% of experimental group cows, the duration of the service period was less than 90 days, whereas in the control group animals with such duration were not detected.

The indicated dependence is also noted for cows of experimental and control groups in a previous experiment for separate use of Cit Citrate. This confirms the conclusion that the combined effect of CME on the reproductive function of cows in the applied doses can be attributed to a greater extent by Cit Citrate. Perhaps the level of total positive effect from the applied complex additive Cit, Se, Cr, J, Co and $\mathrm{Zn}$ is limited to their antagonistic bonds, as well as the physiological capabilities of the reproductive system of cows.

Consequently, the inclusion of Se citrate in the diet of cows in the first period of lactation causes an increase in their reproductive function, this effect is maintained and in combination with its citrate $\mathrm{J}, \mathrm{Cr}$, Co and Zn.

Presenting $2.5 \mu \mathrm{g} \mathrm{Cr} / \mathrm{kg} \mathrm{m}$. T in the form of citrate obtained by the method of nanotechnology in the next experiment increased the resistance and reproductive function of their organism. In particular, in the blood of the Krolematik D 1 group under the action of $66 \mathrm{H} 5 \mathrm{CrO}$, a higher level $(p<0.05)$ of non-specific resistance of the organism - phagocytic blood activity, lysozyme and BASK was found (Table 1). The use of $\mathrm{Cr}$ in combination with $\mathrm{Na}$ sulfate resulted in a similar increase in these blood parameters in the D-2 group, but with a higher degree of likelihood of differences in LA and BASK $(p<0.01)$. These results confirm the data we obtained earlier in our experiments on pigs. It was shown that the activity of citrate $\mathrm{Cr}$ in the blood of sows increased the erythropoietic function and activity of leukocytes before and after fertilization [4].

Table 1. Indicators of non-specific resistance of the body of the rabbit during the release of chromium citrate and sodium sulfate $(M \pm m, n=4)$

\begin{tabular}{|l|c|c|c|c|c|}
\hline \multirow{2}{*}{ Group } & \multicolumn{5}{|c|}{ Indexes } \\
\cline { 2 - 6 } & FA, \% & FI, од. & FX, од. & LA, \% & BASK, \% \\
\hline C & $48,0 \pm 0,91$ & $7,89 \pm 0,37$ & $3,90 \pm 0,14$ & $49,25 \pm 1,79$ & $52,64 \pm 1,11$ \\
\hline D-1 & $50,25 \pm 0,62^{*}$ & $7,95 \pm 0,32$ & $4,01 \pm 0,22$ & $58,0 \pm 1,77^{*}$ & $57,40 \pm 1,28^{*}$ \\
\hline D-2 & $52,75 \pm 1,49^{*}$ & $8,12 \pm 0,33$ & $4,07 \pm 0,21$ & $57,5 \pm 0,64^{* *}$ & $59,14 \pm 0,69^{* *}$ \\
\hline
\end{tabular}

Consequently, as a separate release of $\mathrm{Cr}$-Cr-proteins, and its combination with $\mathrm{Na}$ sulfate, the functional activity of neutrophils of peripheral blood, their lysozyme and bactericidal activity during lactation increased. The state of the humoral link of the immune system of the krolatots significantly influenced their reproductive function and the formation of the body's resistance to the offspring. In particular, the number of births of rabbits in the D 1 group was 48, or 9.6 per kilo (102\%), and for D 2 - 50 (10 per klo-em), or $106 \%$ compared to the control (fig. 3). The highest retention of crowns is noted in the Krolematites D 2 group, as evidenced by the number of rabbits (49 in the group or 9.8 per female) at 20 days of lactation. While in the D 1 group, these indicators were kept at the control group level - 46 and 9.2 respectively. 

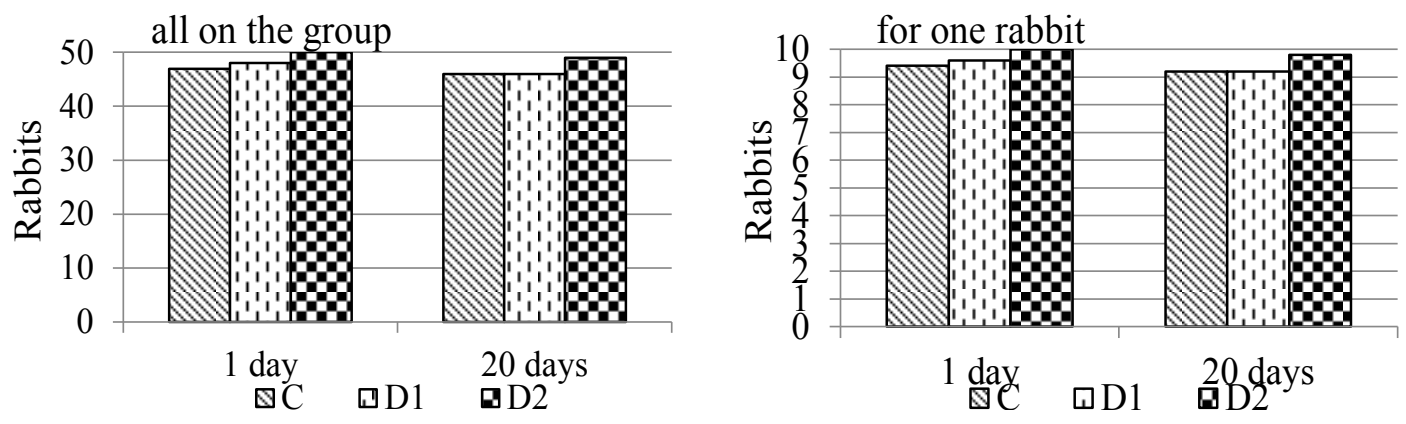

Fig. 3. The fertility of the krol'matov and the stability of the rabbits for the effects of the Cr (D1 group) citrate and the $\mathrm{Cr}+\mathrm{Na} 2 \mathrm{SO} 4$ citrate ( $\mathrm{D} 2$ group)

The use of Citrate $\mathrm{Cr}$ and $\mathrm{Na}$ potassium sulfate has improved the growth and development of fruits. In particular, the weight of newborn rabbit in the D 1 group was $66.3 \mathrm{~g}$ or $106 \%$ of this indicator in the control group (Fig. 4-A).
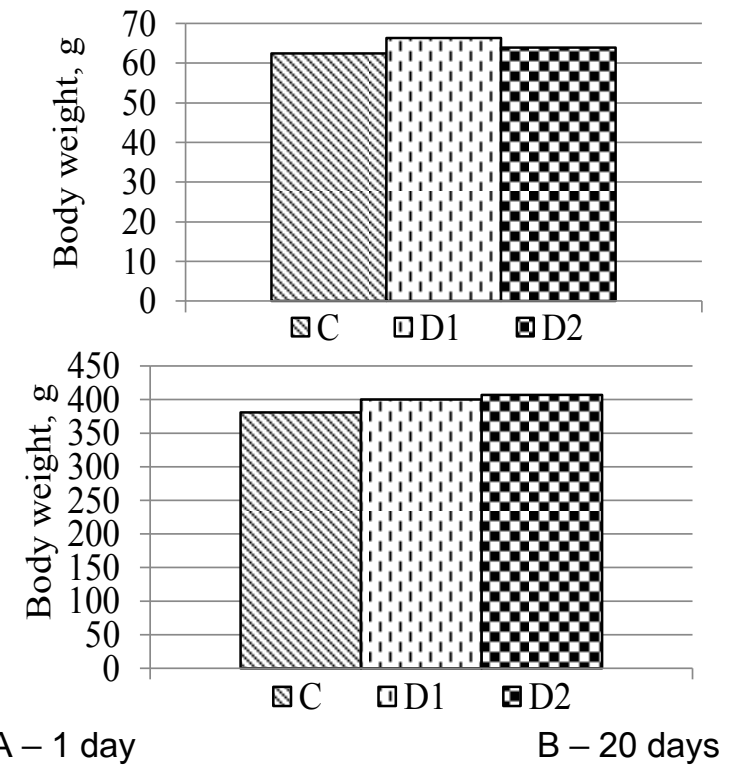

Fig. 4. Average weight of rabbit on $1(A)$ and 20 (B) days after birth, $g$

However, the combination of $\mathrm{Cr}$ and $\mathrm{Na}$ sulfate in the rabbit $\mathrm{D} 2$ group resulted in an increase in the mass of born proteins only by $2.4 \%$. While the release of these compounds to the cholerae with the litter during 20 days of lactation contributed to an increase in the body weight of the rabbits by 5 and $7 \%$, respectively, in groups 1 and 2 (Fig. 4B), which may be due to the milk yield of the krolematok.

Because $\mathrm{Cr}$ compounds in the animal organism activate carbohydrate, lipid and protein metabolism, they increase the tissue susceptibility to insulin action [3, 6], and $\mathrm{Na} 2 \mathrm{SO} 4$ stimulates the lactation function of females, combined with the use of $\mathrm{Cr} \mathrm{Cr}$ and $\mathrm{Na}$ sulfate apparently exacerbated the metabolic action of these compounds and the milk of the krolematik .

\section{Conclusions}

1. The use of citrate Se in feeding cows in the first 2 months of lactation promotes the activation of reproductive function of their body, with a decrease in the number of inseminating inseminals by 17.4$30.4 \%$ and service period by $36.2-46.1 \%$.

2. The complex application of citrate Se in combination with citrates $\mathrm{J}, \mathrm{Co}, \mathrm{Cr}$ and $\mathrm{Zn}$ contributed to a decrease in the amount of inseminating inseminating by $18.2 \%$, and the service - a period of $28.3-29.0 \%$ compared with control. 
3. The release of $\mathrm{Cr}$ Cret per kilogram of $\mathrm{Cr}$ crude at a rate of $2.5 \mu \mathrm{g} \mathrm{Cr} / \mathrm{kg}$ and its combination with $\mathrm{Na} 2 \mathrm{SO} 4$ at a rate of $41 \mathrm{mg} \mathrm{S} / \mathrm{kg} \mathrm{m}$. Increased the resistance and reproductive function of their organism with an increase in the number and weight of newborn baby strains, Their preservation.

\section{Bibliography}

1. Косенко М. В. Відтворення молочного поголів'я / М. В. Косенко, Б. М. Чухрій, О. І. Чайковська // Львів: Українські технології. - 2005. - 228 с.

2. Федорович $€$. Вплив показників відтворної здатності на молочну продуктивність корів / $€$. Федорович, 3. Щербатий, П. Бондар // Тваринництво України. — 2014. — № 2. - С. 38-41.

3. Яблонська О. В. Корекція імунодефіцитних станів глибокотільних корів за допомогою трекрезану, герматранолу та сапоніту / Ветеринарна медицина, 2004. - Вип. 84.- с. 785-790.

4. І Іскра Р. Я. Хром у живленні тварин / Р. Я. Іскра, В. В. Влізло, Р. С. Федорук, Г. Л. Антоняк. — Київ: «Аграрна наука», 2014. - 312 с.

5. Soltan M. A. Effect of dietary chromium supplementation on productive and reproductive performance of early lactating dairy cows under heat stress / J Anim Physiol Anim Nutr (Berl). — 2010. — V. 94(2). - P. 264-272.

6. Патент України на корисну модель № 105684. Спосіб підвищення заплідненості корів / Дейнека М. О., Каплуненко В. Г., Шеремета В. І., Себа М. В. Опубл. 25.03.2016. Бюл. № 6

7. Норми і раціони повноцінної годівлі високопродуктивної великої рогатої худоби: довідникпосібник / за наук. ред. Г.О. Богданова, В.М. Кандиби. - К.: Аграрна наука, 2012. — 296 с.

8. Лесик Я. В. Резистентність організму кролів та динаміка маси тіла кроленят за умов випоювання сполук хрому (III) і сульфату натрію / Я. В. Лесик, Р. С. Федорук, О. П. Долайчук // Біологія тварин, 2014. - Т. 16, № 3. - с. 76-84.

9. Peres L. M. Effect of supplementing finishing pigs with different sources of chromium on performance and meat quality / L. M. Peres, A. M. Bridi, C. A. de Silva, N. Andreo, C. C. P. Barata, Dario J. G. N. // R Bras Zootec. - 2014. - V. 43 (7). - P. 369-375.

10. Guikinglung $P$. Influence of dietary supplementation of chromium on the carcass traits of crossbred pigs / P. Guikinglung, G. P. Tensingh, T. Sivakumar, K. Thilak Pon Jawahar, T. Muthuramalingam, P. J. Pothiappan // Adv Vet Anim Res., 2014. — V. 1 (3). — P. 125-129.

11. Spears J. W. Chromium supplementation in cattle diets. 21st Annual Florida Ruminant Nutrition Symp / University of Florida. — 2010. — P. 143-155.

12. Патент України на корисну модель № 38391. Спосіб отримання карбоксилатів металів «Нанотехнологія отримання карбоксилатів металів» [Текст] / М. В. Косінов, В. Г. Каплуненко. Опубл. 12.01.2009. Бюл. № 1.

13. Сердюк А. М. Нанотехнології мікронутрієнтів: проблеми, перспективи та шляхи ліквідації дефіциту макро- і мікроелементів / А. М. Сердюк, М. П. Гуліч, В. Г. Каплуненко, М. В. Косінов // Журн. АМНУ. - 2010. - Т. 16, № 1. - С. 107-114.

14. Dolaychuk O. P. Physiological Reactivity and Antioxidant Defense System of the Animal Organism Induced by Germanium, Chromium, and Selenium "Nanoaquacitrates" / O. P. Dolaychuk, R. S. Fedoruk, S. J. Kropyvka // Agricultural science and practice. — 2015. — №2. —C. 50-55.

15. Шаторна В. Ф. Дослідження впливу нанометалів на стан репродуктивної функції в ембріогенезі / В. Ф. Шаторна, В .1. Гарець, О. О. Савенкова [та ін.] // Таврический медикобиологический вестник. - Матеріали IV Національного конгресу АГЕТ України. - Сімферополь. 2013. — № 1, T. 16, ч. 1. - С. 246-251.

16. Влізло В. В. Лабораторні методи досліджень у біології, тваринництві та ветеринарній медицині: довідник / В. В. Влізло, Р. С. Федорук, І. Б. Ратич та ін. — Львів: СПОЛОМ, 2012. - 764 с. 